\title{
THE HAGUE EVIDENCE CONVENTION REVISITED: REFLECTIONS ON ITS ROLE IN U.S. CIVIL PROCEDURE
}

\author{
GARY B. BORN*
}

INTRODUCTION

This article proposes a reworking of the basic terms of the Hague Evidence Convention. Under current law, U.S. courts typically do not employ the Convention's evidence-taking mechanisms when ordering discovery from either a litigant or a witness subject to the court's subpoena power. Instead, applying a comity analysis adopted in Société Nationale Industrielle Aérospatiale v. United States District Court for the Southern District of Iowa, ${ }^{1}$ lower courts allow use of the direct discovery provisions of the Federal Rules of Civil Procedure. United States courts will usually require use of the Convention only when direct U.S. discovery is not available (as in the case of witnesses not subject to U.S. subpoena power).

At the same time, foreign courts executing letters of request under the Convention generally will not provide U.S. litigants with assistance adequate for their purposes. Foreign courts usually regard U.S. discovery requests as impermissibly broad and, relying on their reservations under Article $23,{ }^{2}$ refuse to execute such requests. When discovery is permitted, it often takes longer than U.S. litigants find acceptable.

Both the United States and foreign nations are critical of this state of affairs. United States courts and litigants are saddled with what they describe as the awkward, unpredictable Aérospatiale comity analysis; they do not obtain useful assistance when resort to the Convention is required; and their judgments may not be enforceable abroad. At the same time, foreign nations resent unilateral U.S. discovery of materials located on their territory, which often violates local blocking statutes.

A new compromise might be more satisfying. As part of this compromise, foreign states would replace their Article 23 reservations with undertakings to execute letters of request for information that is "material" to a foreign litigation, subject only to specifically recognized foreign privileges. This

\footnotetext{
Copyright (C) 1994 by Law and Contemporary Problems

* Partner, Wilmer, Cutler \& Pickering, Washington, D.C. and London. The views contained in this article are personal ones of the author and do not necessarily reflect the positions of his firm or any of its clients.
}

1. 482 U.S. 522 (1987)

2. See infra note 5 and accompanying text. 
commitment would include an obligation to provide requested materials within a specified time (for example, three months). In return, the United States would commit to requiring first-use of the Convention. In addition, the United States would forbid direct U.S. discovery except where a foreign state has breached its commitment to provide relevant information within agreed time limits.

\section{II}

\section{BACKGROUND: THE EXClusivity DEBATE}

The basic terms of the Hague Evidence Convention are familiar. ${ }^{3}$ The Convention's drafters sought to formulate an agreement on evidence-taking methods that would "reconcile the differing legal philosophies of the Civil Law, Common Law, and other systems," permit efficient and effective transnational evidence-taking, and "satisfy doctrines of judicial sovereignty." 4 The Convention attempted to meet these goals by establishing a "Central Authority" mechanism. Under this mechanism, signatories to the Convention are required to establish Central Authorities-governmental bodies charged with executing various obligations under the Convention. When a court in one signatory state seeks to take evidence located in another signatory state, it may send a "letter of request" to the second state's Central Authority, soliciting its aid in obtaining specified information.

The receiving Central Authority forwards foreign letters of request to the appropriate local court for execution. The central innovation of the Convention requires that court to "apply the appropriate measures of compulsion" in the same fashion as would apply in purely domestic evidence-taking. ${ }^{5}$ Local law governs the "methods and procedures" of evidence-taking under the Convention, although "special method[s] or procedure[s]" may be requested and are ordinarily to be followed (unless "incompatible with the internal law of the State of execution or . . impossible of performance"). ${ }^{6}$ The Convention also requires that letters of request must be executed "expeditiously."

With two principal exceptions, the receiving state is obliged by the Convention to execute incoming letters of request. First, a signatory state may

3. There exists extensive commentary describing the Convention and its preparation. See GARY BORN \& DAVID WESTIN, INTERNATIONAL CIVIL LITIGATION IN UNITED STATES COURTS 411-47 (2d ed. 1992) (citing authorities).

4. Rapport de la Commission speciale, 4 Conference de La Haye de droit international prive: Actes et documents de la Onzieme session 55 (1970); see MESSAGE FROM THE PRESIDENT OF THE UNITED STATES TRANSMITTING THE CONVENTION ON THE TAKING OF EVIDENCE ABROAD IN CIVIL OR COMmercial MATTERS, S. EXEC. DoC. No. A, 92d Cong., 2d Sess. (1972), reprinted in 12 INT'L LEGAL MAT. 323 (1973); LETTER OF SUBMITTAL From SECRETARY OF STATE WILliaM P. Rogers to the President Regarding THE Evidence Convention, S. ExeC. DoC. No. A.1, 92d Cong., 2d Sess. (1972), reprinted in 12 INT'L LEgAL MAT. 324 (1973); SENATE COMM. ON FOREIGN RELATIONS, Evidence Convention, S. ExeC. ReP. No. 25, 92d Cong., 2d Sess. 1-2 (1972).

5. Convention on the Taking of Evidence Abroad in Civil or Commericial Matters, opened for signature Mar. 18, 1970, art. 2, 23 U.S.T. 2555, 2561-62, 847 U.N.T.S. 231, 243.

6. Id. art. 9, 23 U.S.T. at 2561,847 U.N.T.S. at 243.

7. Id. 
decline to execute a letter of request if it believes its "sovereignty or security would be prejudiced thereby." 8 Second, signatory states may declare under Article 23 of the Convention that they "will not execute Letters of Request issued for the purpose of obtaining pre-trial discovery of documents as known in Common Law countries." As described below, most signatories have made some sort of reservation under Article 23.

After an initial period of calm, the Convention became the subject of frequent litigation in the United States. The principal issue in this litigation has been the "exclusivity" of the Convention-whether and when U.S. litigants must use the Convention's procedures rather than the more customary route of direct U.S. discovery under the Federal Rules of Civil Procedure or its state counterparts. ${ }^{10}$ Three possible answers to this question emerged in the United States. ${ }^{11}$ First, the Convention might be the exclusive means for obtaining evidence located in a Convention signatory state. Under this view, local discovery provisions, including the Federal Rules of Civil Procedure, are preempted by the Convention. Several signatories to the Convention take this position. $^{12}$ Second, courts might be obliged in some circumstances to make "first-use" of the Convention in obtaining evidence from signatory states. Derived from the doctrine of international comity, this requirement might take the form of either a generally applicable rule or be satisfied through an ad hoc comity analysis in particular cases. ${ }^{13}$ Third, the Convention might simply be inapplicable to evidence-taking from parties subject to the court's personal

8. Id. art. 12,23 U.S.T. at 2562,847 U.N.T.S. at 243 . The Convention's negotiating history suggests that this exception was meant to be narrow.

9. Id. art. 23,23 U.S.T. at 2568,847 U.N.T.S. at 245.

10. U.S. courts have long exercised the power to order litigants (and witnesses) to comply with discovery requests seeking materials located in foreign nations. See RESTATEMENT (THIRD) OF FOREIGN RELATIONS LAW OF THE UNITED STATES $§ 442(1)$ (a) (1987); BORN \& WESTIN, supra note 3 , at 351-66.

11. For commentary on the exclusivity debate, see Stephen B. Burbank, The World in Our Courts, 89 MICH. L. REv. 1456, 1490-95 (1991); Lawrence Collins, The Hague Evidence Convention and Discovery: A Serious Misunderstanding?, 35 INT'L \& COMP. L.Q. 765 (1986); John N. Rogers, On the Exclusivity of the Hague Evidence Convention, 21 TEX. INT'L L.J. 441 (1986).

12. Brief for the Republic of France as Amicus Curiae in Support of Petitioners at 2, 4, 8-9, 12-16, Société Nationale Industrielle Aérospatiale v. United States Dist. Ct. for the So. Dist. of Iowa, 482 U.S. 522 (1987) (No. 85-1695) ("The Republic of France strongly believes that the language and negotiating history of the Convention demonstrate that it sets forth mandatory procedures by which evidence located abroad may alone be sought, unless the foreign sovereign permits otherwise."); Brief for the Federal Republic of Germany as Amicus Curiae in Support of Petitioners at 11-12, Aérospatiale (No. 85-1695); Brief of Government of Switzerland as Amicus Curiae in Support of Petitioners at 4, 13-14, Aérospatiale (No. 85-1695) ("Use of the Convention should be mandated in all cases in which evidence is sought from abroad.").

13. E.g., Philadelphia Gear Corp. v. American Pfauter Corp., 100 F.R.D. 58 (E.D. Pa. 1983); Gebr. Eickhoff Maschinenfabrik und Eisengieberei mbH v. Starcher, 328 S.E.2d 492 (W. Va. 1985); Vincent v. Ateliers de la Motobecane, S.A., 475 A.2d 686 (N.J. Super. Ct. App. Div. 1984); Th. Goldschmidt A.G. v. Smith, 676 S.W.2d 443 (Tex. Ct. App. 1984). Alternatively, the Convention might be a wholly optional means of obtaining evidence from signatory states. Under this view, U.S. courts could freely require compliance with direct discovery requests under domestic law, but could also permit resort to the Convention in appropriate cases. 
jurisdiction. Under this view, the Convention would apply only to discovery from nonparty witnesses. ${ }^{14}$

In Société Nationale Industrielle Aérospatiale v. United States District Court for the Southern District of Iowa ${ }^{15}$ the Supreme Court resolved the exclusivity debate within the United States. ${ }^{16}$ The Court held unanimously that the Convention was not the exclusive means of obtaining evidence located in a signatory state. Nonetheless, all nine Justices agreed that international comity required first-use of the Convention, at least in some cases. The Aérospatiale court divided sharply, however, over the precise meaning of the comity doctrine. Five justices held that comity required only an ad hoc, case-by-case balancing of foreign and U.S. interests, whereas four Justices concluded that comity imposed a general first-use requirement. ${ }^{17}$ According to the majority, the Convention provides only optional procedures and does not "require any contracting [s]tate to use" these procedures. ${ }^{18}$ The majority nevertheless held that international comity required lower courts to consider a variety of factors on a case-by-case basis in determining whether to require first-use of the Convention, including: (1) U.S. sovereign interests; (2) the sovereign interests of the relevant foreign state; (3) the likelihood that resort to the Convention's procedures would be effective; (4) the breadth and intrusiveness of the requested discovery; and (5) the special difficulties that foreign litigants encounter in responding to U.S.-style discovery. ${ }^{19}$ The Court flatly refused to provide further guidance: "We do not articulate specific rules to guide this delicate task of adjudication." 20

Four dissenting Justices preferred a general rule of first-use of the Convention, subject to a futility exception. The dissent thought that "[t]he principle of comity leads to more definite rules than the ad hoc approach endorsed by the majority," ${ }^{21}$ and it warned that the Court's ad hoc comity analysis "will be performed inadequately and that the somewhat unfamiliar procedures of the Convention will be invoked infrequently."22

14. See In re Société Nationale Industrielle Aérospatiale, 782 F.2d 120, 125 (8th Cir. 1986).

15. 482 U.S. 522 (1987).

16. In a little-publicized recent decision, the English High Court of Justice reached essentially the same result as Aérospatiale. Partenreederei M/S "Heidberg" v. Grosvenor Grain and Feed Co. Ltd decision, 2 Lloyd's Rep. 324 (Q.B. (Commercial Court) 1993) (LEXIS, Intlaw library, UK Case file) (holding that plaintiffs could proceed under English discovery rules in seeking documents located in France under the control of French defendants). The court, quoting from Aérospatiale, specifically rejected the argument that discovery had to be sought through the Hague Evidence Convention.

17. The majority opinion was delivered by Justice Stevens and joined by Chief Justice Rehnquist and Justices White, Powell, and Scalia. Justice Blackmun wrote an opinion dissenting in part and concurring in part, joined by Justices Brennan, Marshall, and O'Connor.

18. 482 U.S. at 534.

19. Id. at 544-46.

20. Id. at 546 .

21. Id. at 554.

22. Id. at 548 . 


\section{III}

\section{CONFlicting National Policies in Transnational Discovery DISPUTES}

Conflicting national interests underlie the debate over the Convention's exclusivity. On the one hand, the United States regards broad, expeditious, party-directed discovery of materials located abroad as essential to fair international civil litigation in U.S. courts. On the other hand, many foreign nations see coerced discovery of materials on their territory as violative of both national sovereignty and local privacy expectations, because their domestic systems permit significantly narrower "discovery" and do not grant litigants a substantial role in the process. Collisions between these U.S. and foreign national approaches have been frequent and sharp: "No aspect of the extension of the American legal system beyond the territorial frontier of the United States has given rise to so much friction as the requests for documents in investigation and litigation in the United States."23

\section{A. U.S. Objectives and Interests in Transnational Discovery Disputes}

The United States has significant interests in transnational discovery disputes. In summary, the U.S. objectives are: (1) to enable litigants in U.S. courts to obtain customarily broad U.S.-style discovery; (2) to enable litigants in U.S. courts to obtain such discovery expeditiously and economically; and (3) to ensure that opposing litigants in U.S. courts enjoy equal discovery opportunities.

In Aérospatiale, the U.S. Government's amicus curiae brief argued that "[ $t$ ]he central domestic interest is generally the same in any international discovery dispute: The United States has a fundamental obligation to assure that domestic litigants are afforded adequate opportunities to adjudicate their claims." ${ }^{24}$ The U.S. Government further asserted that this interest has long included the right to obtain discovery that is unusually broad by international standards. ${ }^{25}$ Thus, U.S. procedural rules permit discovery of all nonprivileged material relevant to the subject matter of the parties' dispute, including material that will not be admissible as evidence. ${ }^{26}$

A closely related U.S. interest concerns obtaining discovery efficiently. Again, the U.S. Government's amicus brief in Aérospatiale observes that "the

23. Restatement (Third) OF Foreign Relations Law OF the UNITEd States $\$ 442$, Reporters' Note 1 (1987).

24. Brief for the United States as Amicus Curiae at 21, Société Nationale Industrielle Aérospatiale v. United States Dist. Ct. for the So. Dist. of Iowa, 482 U.S. 522 (1987) (No. 85-1695).

25. The government cited the broad discovery provisions of the Federal Rules of Civil Procedure in support of this. Id. at 21-22 (citing Seattle Times Co. v. Rhinehart, 467 U.S. 20, 30, $36 \mathrm{n} .22$ (1984); Herbert v. Lando, 441 U.S. 153, 177 (1979); Hickman v. Taylor, 329 U.S. 495, 500 (1947)). As the Court remarked in Aérospatiale, "[i]t is well known that the scope of American discovery is often significantly broader than is permitted in other jurisdictions." 482 U.S. at 542.

26. FED. R. CIV. P. 26; see Wayne D. Brazil, The Adversary Character of Civil Discovery: A Critique and Proposals for Change, 31 VAND. L. REV. 1295 (1978). 
ultimate goal of the Federal Rules is efficient as well as effective discovery."27 In turn, the Aérospatiale court emphasized the need for prompt discovery and commented that "the Letter of Request procedure authorized by the Convention would be unduly time consuming and expensive."28 Similarly, post-Aérospatiale decisions have emphasized the importance of efficient discovery. ${ }^{29}$

Finally, the United States has an interest in ensuring equal discovery opportunities. In particular, foreign litigants should not be able to make use of broad U.S. discovery mechanisms while invoking the Convention to avoid direct U.S. discovery of their own materials located abroad. The Court in Aérospatiale advanced this very point: a rule of first-use of Convention procedures would produce an "unacceptable asymmetr[y]" because "within any lawsuit between a national of the United States and a national of another contracting party, the foreign party could obtain discovery under the Federal Rules of Civil Procedure, while the domestic party would be required to resort first to the procedures of the Hague Convention." 30

\section{B. Foreign Objectives and Interests in Transnational Discovery Disputes}

Foreign interests in transnational discovery disputes in U.S. courts have thus far been expressed through resistance to extraterritorial U.S. discovery. The fundamental foreign objections to U.S. extraterritorial discovery are (1) its breadth, inevitably described abroad as allowing "fishing expeditions", and (2) its failure to involve local judicial officials.

First, foreign nations-both civil and common law-object to the breadth of U.S. pre-trial discovery. As described above, U.S. procedural rules permit coerced discovery of all material relevant to the parties' dispute. The scope of evidence-taking in civil cases in virtually all foreign nations-including

27. Brief for the United States as Amicus Curiae at 22, Aérospatiale (No. 85-1695). The U.S. Government's brief contained a section describing the experiences of the Securities and Exchange Commission (the "SEC") in using the Convention. Among other things, the SEC complained about delays that it had encountered when foreign deponents resisted discovery and about the amounts of information that it received. Id. at 15-19.

28. 482 U.S. at 542 .

29. See infra Part IV. From a non-U.S. perspective, U.S. concerns about quick, efficient discovery are in considerable tension with demands for expansive, party-controlled discovery. See, e.g., John H. Langbein, The German Advantage in Civil Procedure, 52 U. CHI. L. REV. 823 (1985).

30. 482 U.S. at 540 n.25. 
Germany, ${ }^{31}$ France, $^{32}$ England, ${ }^{33}$ and Switzerland ${ }^{34}$-is substantially more limited.

Against this background, many foreign states have vigorously resisted broad U.S. court-ordered discovery of materials from their territory. This resistance has taken the form of diplomatic protests, ${ }^{35}$ blocking statutes, ${ }^{36}$ and Article 23 reservations. France, for example, has enacted blocking legislation that seeks to "prohibit 'legal tourism,' that is, unfocused demands for documents by foreign lawyers acting without court supervision." 37 In addition, both the United Kingdom and Germany have refused to execute letters of request under the Convention and letters rogatory seeking broad, U.S.-style discovery. ${ }^{38}$

Second, many foreign nations also object to the manner in which extraterritorial U.S. discovery is conducted-particularly the fact that it is largely controlled by private litigants rather than by a judicial authority. Many countries' approaches to factual investigation in connection with litigation differ significantly from the U.S. method. ${ }^{39}$ In many civil law nations, the investigation of factual matters is largely controlled by the trial judge; the litigants' attorneys are not expected, nor able, to play the role in "discovery" that U.S. litigators do. These nations regard judicial supervision of the discovery of materials located on their territory as important to their national sovereignty and as a necessary safeguard for nationals against undue coercion. ${ }^{40}$

31. David J. Gerber, Extraterritorial Discovery and the Conflict of Procedural Systems: Germany and the United States, 34 AM. J. COMP. L. 745 (1986); Benjamin Kaplan et al., Phases of German Civil Procedure, 71 HARV. L. REV. 1193 (1958); Langbein, supra note 29.

32. Jacques Borel \& Stephen M. Boyd, Opportunities for and Obstacles to Obtaining Evidence in France for Use in Litigation in the United States, 13 INT'L LAw. 35 (1979); Brigitte E. Herzog, The 1980 French Law on Documents and Information, 75 AM. J. INT'L L. 382 (1981); Bate C. Toms III, The French Response to the Extraterritorial Application of United States Antitrust Laws, 15 INT'L LAW. 585 (1981).

33. Paul Matthews \& Hodge M. Malek, Discovery 89-109 (1992); Lawrence Collins, Opportunities For and Obstacles to Obtaining Evidence in England for Use in Litigation in the United States, 13 INT'L LAW. 27 (1979).

34. Marc G. Corrado, Comment, The Supreme Court's Impact on Swiss Banking Secrecy: Société Nationale Industrielle Aérospatiale v. U.S. District Court, 37 AM. U. L. REV. 827 (1988).

35. See Bernard H. Oxman, The Choice Between Direct Discovery and Other Means of Obtaining Evidence Abroad: The Impact of the Hague Evidence Convention, 37 U. MIAMI L. REv. 733, 764-65 (1983).

36. E.g., Protection of Trading Interests Act, 1980; France, Statute No. 80-538, J.O. 1799 (17 juillet 1980); Netherlands, Statute enacted on June 28, 1956.

37. Brief for the Republic of France as Amicus Curiae at 22, Aérospatiale (No. 85-1695)

38. See infra pp. 84-86; see also BORN \& WESTIN, supra note 3.

39. BORN \& WESTIN, supra note 3, at 346-50; Gerber, supra note 31, at 745; Diana L. Muse, Note, Discovery in France and the Hague Convention: The Search for a French Connection, 64 N.Y.U. L. REV. 1073 (1989).

40. Brief for the Federal Republic of Germany as Amicus Curiae at 6-7, Anschuetz \& Co., GmbH v. Mississippi River Bridge Authority 474 U.S. 812 (1985) (No. 85-98) ("The Federal Republic of Germany likewise considers it a violation of its sovereignty when a foreign court forces, under the threat of sanctions, a person under the jurisdiction of German courts to remove documents located in Germany to the United States for the purpose of pre-trial discovery, or orders a person, under the threat of sanctions, to leave the Federal Republic of Germany and travel to the United States to be available for oral depositions. The taking of evidence is a judicial function exclusively reserved to the courts of the Federal Republic of Germany."); Note of the Federal Republic of Germany to the U.S. Department of State (April 8, 1986) (on file with author); Id. at Exhibit A; Brief of Government of 


\section{Article 23 Reservațions}

Both of these concerns are reflected in the reservations of foreign states to the Convention and in foreign judicial decisions applying the Convention. Most foreign signatories to the Convention-including Germany, the United Kingdom, France, Italy, and Sweden-have adopted significant reservations under Article 23. ${ }^{41}$ These reservations fall into two general categories. A number of Article 23 reservations extend to all requests for pre-trial discovery of documents, including those of Argentina, Italy, Luxembourg, Monaco, Portugal, and Spain. ${ }^{42}$

A larger number of nations have adopted only "partial" reservations under Article 23. The earliest of these reservations, which served as a model for other signatories, was that of the United Kingdom. The U.K. reservation provided:

In accordance with Article $23 \ldots$ the United Kingdom will not execute Letters of Request issued for the purpose of obtaining pretrial discovery of documents. [The United Kingdom] understand[s] "Letters of Request issued for the purpose of obtaining pretrial discovery of documents" for the purposes of the foregoing Declaration as including any Letter of Request which requires a person: (a) to state what documents relevant to the proceedings to which the Letter of Request relates are, or have been, in his possession, custody or power; or (b) to produce any documents other than particular documents specified in the Letter of Request as being documents appearing to the requesting court to be, or to be likely to be, in his possession, custody or powers. ${ }^{43}$

Other nations have adopted similar reservations, including Cyprus, Denmark, Finland, the Netherlands, Norway, Singapore, and Sweden. ${ }^{44}$

There has been a significant, but by no means unanimous, movement away from unqualified Article 23 reservations toward partial reservations. ${ }^{45}$ France, for example, initially adopted an unqualified reservation under Article $23,{ }^{46}$ but subsequently modified its declaration to permit a measure of pre-trial document discovery, if "the requested documents are limitatively enumerated in the letter of request and have a direct and clear nexus with the subject matter of the

Switzerland as Amicus Curiae in Support of Petitioners at 3, 8, Aérospatiale (No. 85-1695) ("If a U.S. court unilaterally attempts to coerce the production of evidence located in Switzerland, without requesting governmental assistance, the U.S. court intrudes upon the judicial sovereignty of Switzerland."); Brief for the the Republic of France as Amicus Curiae in Support of Petitioners at 1215, Aérospatiale (No. 85-1695).

41. 28 U.S.C.A. \$ 1781, Convention on the Taking of Evidence Abroad in Civil or Commercial Matters, Chapt. 1, Art. 42 passim. (West 1994) [hereinafter Convention]. The exceptions are the United States, Czechoslovakia, Israel, and Barbados, which have not made Article 23 reservations.

42. Id.

43. Id. at n.22.

44. Id. passim.

45. Hague Conference on Private International Law (checklist drawn up by Adair Dyer for the Discussions of the Special Commission of April 1989 on the Operation of the Hague Conventions on the service of Process Abroad and on the Taking of Evidence Abroad 28).

46. At the time of its accession, France declared that "in application of Article 23, it will not execute Letters of Request issued for the purposes of obtaining pre-trial discovery of documents as known in Common Law countries." Convention, supra note 41, at n.8. 
litigation." ${ }^{47}$ Other Convention signatories have made similar modifications, ${ }^{48}$ and Germany has for some time been moving toward implementation of a partial reservation. ${ }^{49}$

In practice, even partial Article 23 reservations have posed substantial obstacles to customary U.S.-style discovery. Experiences in the United Kingdom provide a good example. The execution of letters of request under the Hague Evidence Convention in the United Kingdom is governed by the Evidence (Proceedings in Other Jurisdictions) Act, ${ }^{50} 1975$, which was enacted to implement the Convention. Among other things, the Act (and in particular, section 2(4) of Orders issued under it) permit execution of letters of request only as to "particular documents specified" in such letters. ${ }^{51}$ Applying the Act, English courts have issued two significant decisions on the available scope of evidence-taking that may be obtained pursuant to the Convention: Rio Tinto Zinc Corp. v. Westinghouse Elec. Corp. ${ }^{52}$ and In re Asbestos Insurance Coverage Cases. ${ }^{53}$

These decisions make it clear that the scope of discovery that English courts are willing to provide under the Convention is significantly narrower than the scope available under U.S. procedural rules. For example, in the Westinghouse cases, Lord Diplock said that "[t]he requirements of [section 2](4)(b) . . . are not in my view satisfied by the specification of classes of documents. What is called for is the specification of 'particular documents' which I would construe as meaning individual documents separately described." 54 Lord Fraser elaborated on what this requirement meant in the Asbestos Insurance cases:

I do not think that by the words "separately described" Lord Diplock intended to rule out a compendious description of several documents provided that the exact document in each case is clearly indicated. . . [A]n order for production of the Respondent's "monthly bank statements for the year 1984 relating to his current account" with a named bank would satisfy the requirements of the paragraph, provided that the evidence showed that regular monthly statements had been sent to the respondent during the year and were likely to be still in his possession. But a general request for "all the respondent's bank statements for 1984" would in my view refer to a class of documents and would not be admissible. The second test of particular documents is that they must be actual documents, about which there is evidence which has satisfied the judge that they exist, or at least that they did exist, and that they are likely to be in the respondent's possession. ${ }^{55}$

47. Letter from J.B. Raimond, Minister of Foreign Affairs, France, to H.H. Broek, Minister of Foreign Affairs, The Netherlands (Dec. 24, 1986), cited in Société Nationale Industrielle Aérospatiale v. United States Dist. Ct. for the So. Dist. of Iowa, 482 U.S. 522, 564 n.22 (1987).

48. In particular, Sweden, Denmark, and Finland modified their Article 23 reservations on July 11, 1980, July 23, 1980, and December 11,1980 respectively. Convention, supra note 41 , at n.21, n.6, n.7.

49. A. Bradley Shingleton, Document Production in the Federal Republic of Germany: Progress and Problems, in Germany Through American Eyes 117, 121-25 (Gale A. Mattox \& John H. Vaughan, Jr. eds., 1989).

50. Evidence Act, 1975, ch. 34 (Eng.).

51. Id. \& 2(4).

52. [1978] App. Cas. 547, 1 C.M.L.R. 100 (House of Lords 1977).

53. [1985] 1 W.L.R. 331.

54. [1978] App. Cas. at 635.

55. 1 W.L.R. at 337-38 (quoting Slade, L.J. (citation omitted)). 
Applying this test, the court strikingly demonstrated the effect of Article 23 on U.S.-style discovery by refusing to enforce virtually all of a U.S. letter of request seeking both documents and deposition testimony. ${ }^{56}$

\section{IV}

\section{The Hague Evidence Convention as Applied by U.S. Courts AfTer AEROSPATIALE}

Since Aérospatiale, lower courts have handed down about fifteen reported decisions concerning first-use of the Convention. These decisions, together with several unreported opinions, provide the basis for some interim conclusions concerning the current role of the Convention in U.S. pretrial discovery. ${ }^{57}$

Lower U.S. courts have almost uniformly refused to require litigants to resort to the Convention's procedures when seeking discovery within the United States from other parties. In eight published decisions (and several unpublished cases), lower courts have permitted litigants to seek discovery directly under the Federal Rules of Civil Procedure. ${ }^{58}$ Most of these decisions have relied on a mix of perceptions, including that (1) discovery under the Convention produces unduly limited amounts of material; (2) discovery under the Convention is slow; (3) foreign nations typically do not have significant interests in limiting U.S. discovery; and (4) U.S. interests in prompt, complete pretrial discovery are of overriding importance.

Several recent lower court decisions illustrate this general observation. In Benton Graphics v. Uddeholm Corp.,${ }^{59}$ the trial court considered whether to require that plaintiff's interrogatories and document requests be made under the Convention. Applying the Aérospatiale analysis, the court concluded that discovery should proceed under the Federal Rules. The court emphasized its view that the Convention's procedures would be slow:

56. On the other hand, it would appear that the Convention is being implemented somewhat more quickly as experience is gained with its terms. The Master's Secretary's Department has provided the following statistics concerning execution of U.S. letters of request in England:

$\begin{array}{ccc}\text { Year } & \text { Number of Requests } & \text { Average Time to Execute } \\ 1988 & 12 & 7 \mathrm{mos} \\ 1989 & 26 & 5 \mathrm{mos} \\ 1990 & 31 & 4 \mathrm{mos} \\ 1991 & 30 & 51 / 2 \mathrm{mos} \\ 1992 \text { (YTD) } & 21 & 4 \mathrm{mos}\end{array}$

Letter to Gary B. Born from Master's Secretary's Department (Nov. 1992) (on file with author).

57. The same issues were addressed in Gary Born \& Scott Hoing, Comity and the Lower Courts: Post-Aérospatiale Applications of the Hague Evidence Convention, 24 INT'L LAW. 393 (1990). Subsequent developments in the lower courts are consistent with the conclusions in that article.

58. Doster v. Schenk, 141 F.R.D. 50 (M.D.N.C. 1991); Great Lakes Dredge \& Dock Co. v. Harnischfeger Corp., 1990 U.S. Dist. LEXIS 12843 (N.D. Ill. Sept. 25, 1990); In re Bedford Computer Corp., 114 B.R. 2 (Bankr. D.N.H. 1990); Haynes v. Kleinwefers, 119 F.R.D. 335 (E.D.N.Y. 1988); Rich v. KIS Cal., Inc., 121 F.R.D. 254 (M.D.N.C. 1988); Benton Graphics v. Uddeholm Corp., 118 F.R.D. 386 (D.N.J. 1987); Scarminach v. Goldwell GmbH, 531 N.Y.S.2d 188 (N.Y. App. Div. 1988); Sandsend Fin. Consultants, Ltd. v. Wood, 743 S.W.2d 364 (Tex. Ct. App. 1988).

59. 118 F.R.D. 386 (D.N.J. 1987). 
The [Swedish Government] states that the defendant's letter of request should be processed by the Swedish authorities in approximately two months. That is an approximation based upon past history; there are certainly no guarantees. This case has already endured numerous delays and discovery should proceed apace. Another delay while the Swedish authorities determine what discovery will be permitted and the further litigation undoubtedly spawned by their decision may bring actual discovery to a standstill. ${ }^{60}$

The court also dismissed the sovereign interests which the Swedish Government had asserted in an affidavit from its Foreign Ministry. According to the district judge, the Swedish interests were "merely general reasons why Sweden prefers civil law discovery procedures to the more liberal discovery permitted under the federal rules." 61 The court demanded something more specific before it would require discovery under the Convention. ${ }^{62}$

Much the same pattern appeared in the magistrate's opinion in Rich $v . K I S$ California, Inc. ${ }^{63}$ A French defendant had resisted the plaintiff's document requests and interrogatories on the grounds that the Convention should be used in the first instance. Applying Aérospatiale, the magistrate refused to require resort to the Convention. He concluded that no "important sovereign interest of the French nation" was threatened, because the French blocking statute "is both overly broad and vague and need not be given the same deference as a substantive rule of law." ${ }^{4}$ The magistrate also emphasized that "plaintiffs have pared their discovery requests to ten interrogatories limited to the issue of personal jurisdiction." ${ }^{265}$ According to the magistrate, these factors made it clear that the defendants had not met their burden of showing that discovery should proceed pursuant to the Convention. ${ }^{66}$

Although lower U.S. courts have generally refused to require first-use of the Convention, they nonetheless appear to have treated direct extraterritorial discovery from Convention signatories differently from other types of U.S. discovery. In particular, some lower courts have refused to enforce discovery demands under U.S. law as extensively as they otherwise would. These

60. Id. at 391 .

61. Id. The court's attitude towards foreign sovereign interests was consistent with that in Aérospatiale: "The lesson of comity is that neither the discovery order nor the blocking statute can have the same omnipresent effect that it would have in a world of only one sovereign. The blocking statute thus is relevant to the court's particularized comity analysis only to the extent that its terms and its enforcement identify the nature of the sovereign interests in nondisclosure of specific kinds of material." 482 U.S. at 545 n.29.

62. The court continued: "Defendants cite no reasons how the specific discovery sought by Benton implicates any specific sovereign interest of Sweden." 118 F.R.D. at 391.

63. 121 F.R.D. 254 (M.D.N.C. 1988).

64. Id. at 258 .

65. Id.

66. See also Pain v. United Technologies Corp., 637 F.2d 775, 788-90 (D.C. Cir. 1980), cert. denied, 454 U.S. 1128 (1981) ("[T]here can be little doubt that the cost to the litigants of employing such procedures would be exceedingly high."); Doster v. Schenk, 141 F.R.D. 50, 54 (M.D.N.C. 1991) ("[U]se of the Convention procedures in Germany can involve considerable time and expense" and "document requests under [the] Convention would be futile."); In re Bedford Computer Corp., 114 B.R. 2, 6 (Bankr. D.N.H. 1990) ("[T]he only effect of using the Hague Convention rules would be to further delay this adversary proceeding."); International Soc'y for Krishna Consciousness v. Lee, 105 F.R.D. 435, 450 (S.D.N.Y. 1984) (Convention procedures are "quite slow and costly."). 
decisions have relied on the Supreme Court's apparent approval of such an approach in Aérospatiale: "Even if a court might be persuaded that a particular document request was too burdensome or too 'intrusive' to be granted in full, . . . it might well refuse to insist upon the use of Convention procedures before requiring responses to simple interrogatories or requests for admissions."

A leading example of this trend is Benton Graphics, described above. After refusing to require first-use of the Convention, the Court reasoned that "expansive discovery without concomitant relevance is not what the Court envisioned when it handed down the Aérospatiale decision .... [A] number of the requests are not 'simple' and may require streamlining if we are to proceed under the federal rules." 68 The same approach was adopted in In re Bedford Computer Corp., where the court remarked that "the totality of discovery sought in this case is too extensive, unnecessary and intrusive .... The solution is to limit the discovery sought, and still use the [Federal Rules]." ${ }^{69}$

Lower U.S. courts have uniformly required use of the Convention for extraterritorial discovery from persons not subject to party discovery or to subpoena service. In Orlich $v$. Helm Bros., Inc. ${ }^{70}$ for example, the New York Supreme Court, Appellate Division, required that discovery from a foreign nonparty witness proceed pursuant to the Convention. "When discovery is sought from a nonparty in a foreign jurisdiction, application of the Hague Convention ... is virtually compulsory." ${ }^{11}$ Indeed, in cases where a nonparty witness is not subject to U.S. subpoena power, the Convention is generally the only feasible means of obtaining coercive discovery. Rule 45 of the Federal Rules is generally understood as imposing territorial limits on the service of subpoenas such that foreign witnesses, who cannot be served within the United States, are beyond the rule's subpoena power. ${ }^{72}$ Where a Rule 45 subpoena is not available, the Convention ordinarily provides the only effective way to compel discovery from a nonparty witness.

Lower U.S. courts have also required resort to the Convention for discovery - from a party or otherwise-that formally occurs on foreign territory. For example, lower courts have rarely ordered depositions or plant inspections

67. 482 U.S. at $545-46$.

68. Benton Graphics v. Uddeholm Corp., 118 F.R.D. 386, 390 (D.N.J. 1987).

69. 114 B.R. at 6 . This approach is consistent with that adopted towards extraterritorial discovery by $\S 442$ of the RESTATEMENT (THIRD) OF FOREIGN RELATIONS LAW OF THE UNITED STATES (1987).

70. 560 N.Y.S.2d 10 (N.Y. App. Div. 1990).

71. Id. at 14. It is not clear from the court's opinion whether use of the Convention was ordered as a matter of comity or instead was necessary because direct discovery was not available against the nonparty witness.

72. See BORN \& WESTIN, supra note 3, at 357-60. U.S. nationals are subject to more expansive subpoena power. 28 U.S.C. $\$ 1783$ (1988). 'Discovery from nonparty witnesses subject to $\S 1783$ would presumably continue to be available, notwithstanding the witnesses' location in a Hague Evidence Convention signatory, although the Aérospatiale comity analysis might limit or otherwise affect that discovery. 
on the territory of an objecting foreign state, requiring instead use of the Convention. ${ }^{73}$

Largely in reaction to extraterritorial U.S. discovery, a number of foreign states have enacted "blocking statutes." These laws forbid private parties from making information available for use in foreign legal proceedings. ${ }^{74}$ In turn, U.S. courts have reaffirmed their power to order extraterritorial discovery-notwithstanding the fact that such discovery requires foreign parties to violate the law of their own countries. ${ }^{75}$ United States courts, troubled by the imposition of conflicting legal requirements on private parties, have turned to notions of international comity to moderate the reach of extraterritorial discovery orders. ${ }^{76}$ But there remain a significant class of cases in which U.S. courts will sanction private parties for failing to obey U.S. discovery orders, notwithstanding the existence of conflicting foreign blocking statutes.

The reactions of affected parties suggest that in attempting to please everyone, Aérospatiale has not satisfied anybody particularly well. The least satisfied constituency has been U.S. trial courts, who have found the ad hoc Aérospatiale analysis difficult to apply, and who have been unhappy with the results of their handiwork after doing so. Indeed, a number of district judges have criticized the Aérospatiale analysis in unusually direct terms. One district judge commented that "[r]egrettably, the [Supreme] Court [in Aérospatiale] declined to set forth specific rules to guide" decisions on extraterritorial discovery. ${ }^{77}$ Another trial court openly refused to follow the Court's ad hoc comity analysis, instead adopting Justice Blackmun's concurring and dissenting opinion. $^{78}$ Yet another judge agreed with this rejection of the majority's analysis, but reluctantly concluded that he was bound by the Court's decision. ${ }^{79}$

These criticisms are not surprising. The Aérospatiale decision adopted a comity analysis that incorporates an indeterminate number of poorly defined variables into an open-ended balancing test, without indicating priorities. Most significantly, the Court's opinion in Aérospatiale provides virtually no guidance on how the various relevant factors bear on the ultimate resolution of discovery

73. See In re Anschuetz \& Co., GmbH, 754 F.2d 602, 605 (5th Cir. 1985); Jenco v. Martech Int'l, Inc., 1988 U.S. Dist. LEXIS 4727 (E.D. La. May 19, 1988); Scotch Whiskey Ass'n v. Majestic Distilling Co., 14 Fed. R. Serv. 3d (Callaghan) 940 (D. Md. 1988); McLaughlin v. Fellows Gear Shaper Co., 102 F.R.D. 956, 958 (E.D. Pa. 1984); see also In re Sealed Case, 825 F.2d 494, 498 (D.C. Cir.), cert. denied, 484 U.S. 963 (1987) ("[I]t causes us considerable discomfort to think that a court of law should order a violation of law, particularly on the territory of the sovereign whose law is in question.").

74. See BORN \& WESTIN, supra note 3, at 367-73.

75. E.g., Societe Internationale Pour Participations Industrielles et Commerciales, S.A. v. Rogers, 357 U.S. 197 (1958).

76. Reinsurance Co. of America, Inc. v. Administratia Asigurarilor de Stat., 902 F.2d 1275 (7th Cir. 1990).

77. Scarminach v. Goldwell GmbH, 531 N.Y.S.2d 188, 189 (N.Y. App. Div. 1988).

78. Hudson v. Hermann Pfauter GmbH \& Co., 117 F.R.D. 33, 37 (N.D.N.Y. 1987) (announcing that "[t]his court believes that ... the framework offered by Justice Blackmun is preferred.").

79. In Re Perrier Bottled Water Litigation, 138 F.R.D. 348, 354 (D. Conn. 1991). The Court "concurred" with this "preference for Justice Blackmun's approach," but reluctantly concluded that it was obliged to follow the majority's ad hoc comity approach. See Benton Graphics v. Uddeholm Corp., 118 F.R.D. 386, 389 n.2 (D.N.J. 1987). 
disputes. The Court is simply silent on how much weight to attribute to foreign sovereign interests or to U.S. interests, and on when particular balances between national interests mandate first-use of the Convention. As others have observed, the analysis "leaves lower courts, and therefore litigants, quite adrift in deciding what weight to assign the Convention" and "when and where the Convention deserves priority." 80

Foreign states are also dissatisfied with the current Aérospatiale analysis. France, Switzerland, and Germany appeared as amici curiae before the Supreme Court in Aérospatiale, arguing that the Convention was intended to be exclusive. Although they were probably wrong in this contention, these states were naturally disappointed by the Supreme Court's decision. To an extent, their disappointment has increased as U.S. lower courts ignore the Convention's procedures with greater frequency.

Finally, U.S. litigants also have grounds for dissatisfaction with the Aérospatiale analysis. The open-ended comity analysis imposes material costs on both plaintiffs and defendants. Both parties must pay for an unproductive exploration of competing national interests and foreign law. Moreover, U.S. litigants seeking discovery from nonparty witnesses continue to confront broad Article 23 reservations and recalcitrant foreign courts. And parties seeking extraterritorial discovery typically are dissatisfied by the fairly unpredictable "streamlining" of their requests. Furthermore, U.S. litigants who obtain judgments based upon direct U.S. discovery-rather than discovery pursuant to the Convention-may have difficulty enforcing their judgments abroad.

\section{V}

\section{PROPOSALS TO REFORM EXTRATERRITORIAL DisCOVERY FROM HAGUE EVIDENCE CONVENTION SIGNATORIES}

\section{A. The Advisory Committee's "First-Use" Rule}

Dissatisfaction with Aérospatiale's ad hoc comity analysis has prompted several efforts to reform existing U.S. extraterritorial discovery procedures. One proposal to revise the role of the Convention in U.S. procedure was made by the Judicial Conference Advisory Committee on the Federal Rules of Civil Procedure ("Advisory Committee"). In late 1989, the Advisory Committee released a draft of proposed amendments to the Federal Rules of Civil Procedure. The amendments proposed revising Rule 26(a) to state:

If an applicable treaty or convention provides for discovery in another country, the discovery methods agreed to in such treaty or convention shall be employed; but if discovery conducted by such methods is inadequate or inequitable and additional

80. George A. Bermann, The Hague Evidence Convention in the Supreme Court: A Critique of the Aérospatiale Decision, 63 TuL. L. REV. 525, 539-42 (1989); see also Joseph F. Weis, The Federal Rules and the Hague Conventions: Concerns of Conformity and Comity, 50 U. PITT. L. REV. 903 (1989). 
discovery is not prohibited by the treaty or convention, a party may employ the methods here provided in addition to those provided by such convention or treaty. ${ }^{81}$

The clear intent of the drafters of this proposal was to adopt the first-use requirement urged by Justice Blackmun's concurring and dissenting opinion in Aérospatiale. That is, in seeking discovery of materials located within a Hague. Convention signatory, litigants would be obliged first to "employ" the "discovery methods agreed to in such treaty," unless they were "inadequate or inequitable." The explanatory notes accompanying this proposal elaborated its purpose: "to reflect the policy of accommodation to internationally agreed methods of discovery expressed"82 in Justice Blackmun's concurring and dissenting opinion in Aérospatiale. If "certain methods of discovery have been approved for international use, positive international relations require that these methods be preferred." 83

The Committee did not confront significant uncertainties that would have attended efforts to apply its formula in the context of existing Article 23 reservations. Most unclear was how the Advisory Committee's proposal would have applied to discovery from nations with partial Article 23 reservations. In particular, it was not apparent whether the availability of limited discovery, as, for example, in the United Kingdom, would have been deemed "inadequate or inequitable" within the meaning of the Advisory Committee's new Rule 26. If not, then U.S. litigants would have faced very substantially reduced discovery opportunities. If so, then the Convention would have continued to play relatively little part in transnational discovery because of the existence of either partial or unqualified Article 23 reservations in most signatory states. Moreover, even if the Committee had taken a position, it would have either required use of the Convention notwithstanding existing Article 23 reservations, which would have frustrated significant U.S. interests, or permitted direct discovery which would have frustrated significant foreign interests.

At best, the Advisory Committee's proposal might have provided the framework for a dialogue or negotiation between foreign states and U.S. courts concerning use of the Convention: the revised Rule 26 would have created a more explicit incentive for foreign states to permit "adequate" discovery and would have allowed U.S. courts to require first-use of the Convention when this requirement was satisfied. In some respects, Aérospatiale may be seen as having established a similar framework. There are at least three difficulties with this approach. First, the bargaining process was not likely to produce positive results, because it lacked transparency and reliability: foreign states cannot be confident that significant concessions will end direct U.S. discovery. Second, since U.S. judicial decisions are discrete, sporadic statements based on particular facts, they do not foster reliability. And finally, district judges, with their natural focus on deciding individual cases and controlling their dockets, are not

81. Proposed Rules, 127 F.R.D. 237, 318 (1989). For a thoughtful analysis of the authority of the Federal Rules makers to adopt such a proposal, see Burbank, supra note 11, at 1456, 1483-84, $1494-96$.

82. Proposed Rules, supra note 81 , at 320.

83. Id. 
likely to fully reflect broader U.S. interests and are not institutionally suited to participate in an international negotiation:

\section{B. The Advisory Committee's Revised Proposal}

In June of 1989, after sharp criticism of its initial proposal by the Securities and Exchange Commission and others, the Advisory Committee abandoned its proposal to codify Justice Blackmun's first-use test. In a 180-degree reversal, the Advisory Committee proposed a radically altered amendment to Rule 26 . The new proposal would have provided:

Discovery at a place within a country having a treaty with the United States applicable to such discovery shall be conducted by methods authorized by the treaty unless the court determines that those methods are inadequate or inequitable and authorizes other discovery methods not prohibited by the treaty. ${ }^{84}$

The new proposal applied only to discovery that was to be formally conducted "on" the territory of a Convention signatory; examples of this include depositions on foreign territory and inspections of facilities located on foreign territory. The new proposal purportedly would not have applied to the production of documents at a place within the United States (even if the documents had been brought there from abroad) nor to a deposition conducted in the United States (even if the deponent had traveled there from abroad) ${ }^{85}$

This proposed revision to Rule 26 immediately met with vigorous criticism. The most serious opposition came from foreign signatories to the Hague Evidence Convention-notably the United Kingdom and Switzerland. Both nations filed diplomatic notes with the U.S. Department of State, focusing on the new proposal's authorization for coercive discovery to be formally conducted on foreign territory. ${ }^{86}$

This criticism was plainly correct. It has long been accepted that public international law forbids one state from exercising governmental enforcement jurisdiction within the territory of another state without its consent. The Restatement (Third) of Foreign Relations Law of the United States explains: "It

84. Amendments to Federal Rules of Civil Procedure, 134 F.R.D. 525, 641 (1991)(emphasis added).

85. The Advisory Committee Notes accompanying the proposed amendments to Rule 26 made this clear. As those Notes explained:

The rule of comity stated in this rule does not apply to discovery of documents and things from parties who are subject to the court's personal jurisdiction and who may be required to produce such materials at the place of trial. E.g., Insurance Corp. of Ireland v. Compagnie des Bauxites, 456 U.S. 694 (1982). . . . The rule also does not apply to the taking of depositions of parties who may be deposed within the United States. . . . Nor does the rule require comity where the discovery methods available by treaty are "inadequate or inequitable." This provision allows the court to make a discreet [sic] judgment on the facts as to the sufficiency of the internationally agreed discovery methods. . . . Indeed, the court is not precluded by the rule from authorizing, to assure that discovery is adequate and equitable, the use of discovery methods that may violate the laws of another country.

Id. at $642-43$

86. Note from Her Britannic Majesty's Embassy to U.S. Department of State (Feb. 20, 1991) (on file with author). Among other things, the British note said: under the proposed amendments, "a U.S. court might order the holding of a deposition in a foreign country even if doing so were in violation of that country's law or policy. The British Government would consider such an approach to be inconsistent with international law and comity and unacceptable." 
is universally recognized, as a corollary of state sovereignty, that officials of one state may not exercise their functions in the territory of another state without the latter's consent." 87

It is equally well-settled that conducting formal discovery procedures, such as depositions or plant inspections, on foreign territory would violate this restriction on enforcement jurisdiction. The U.S. Government has generally accepted this position. ${ }^{88}$ In its amicus curiae brief in Club Mediterranee, S.A. $v$. Dorin, the United States declared that "[u]nder established principles of both domestic and international law ... American courts are precluded from ordering anyone to participate in discovery proceedings in the territory of a foreign state absent that state's consent; wholly independent of the Evidence Convention." 89

Indeed, as early as the 1870 s, the United States recognized foreign states' concerns about formal discovery proceedings occurring on foreign territory. For example, in 1874 several German diplomatic notes protested against U.S. government officials seeking to take sworn testimony within Germany from German nationals for use in U.S. judicial proceedings. ${ }^{90}$ The United States replied that the evidence was taken by U.S. court-appointed commissioners and that all nations had an interest in facilitating transnational evidence-taking. Germany replied that where the U.S. "system for taking testimony is to be put in force in a foreign country ... then, according to international law, it can only take place with such limitations and under such restrictions ... as is provided by the existing law-forms of the respective foreign countries."91 Germany went on to say that German courts would comply "very cheerfully" with a "letter

87. RESTATEMENT (ThIRD) OF ForEign RELATIONS LAW OF THE UNITED STATES $\$ 432 \mathrm{cmt}$. b (1987); see also The Schooner Exchange v. McFaddon, 11 U.S. (7 Cranch) 116 (1812).

88. The United States's amicus brief in Volkswagenwerk $A G v$. Falzon argued broadly that the Hague Evidence Convention "must be interpreted to preclude an evidence taking proceeding in the territory of a foreign state party if the Convention does not authorize it and the host country does not otherwise permit it." Brief for the United States as Amicus Curiae at 6, Volkswagenwerk AG v. Falzon, 465 U.S. 1014 (1984) (No. 82-1888).

89. Brief for the United States as Amicus Curiae at 9 n.10, Club Mediterranee, S.A. v. Dorin, 462 N.Y.S.2d 524 (N.Y. App. Div. 1983) (No. 83-461), cert. denied, 496 U.S. 913 (1984). In its amicus curiae brief in Aérospatiale, the Solicitor General observed with approval that "this Nation's courts, sensitive to the territorial sovereignty of foreign nations, have generally required use of the Hague Convention where domestic litigants seek the involuntary deposition of a party abroad . . . " Brief for the United States as Amicus Curiae at 25-26, Société Nationale Industrielle Aérospatiale v. United States Dist. Ct. for the So. Dist. of Iowa, 482 U.S. 522 (1987) (No. 85-1695); see also Brief for the Republic of France as Amicus Curiae in Support of Petitioners at 16-17, Aérospatiale (No. 85-1695); Brief for the Federal Republic of Germany as Amicus Curiae at 6, Anschuetz \& Co., GmbH v. Mississippi River Bridge Authority, 474 U.S. 812 (1985) (No. 85-98) (Germany "considers the taking of oral depositions . . . a violation of its sovereignty" unless German governmental authorities approve.).

90. Letter from Mr. von Bülow to George Bancroft (June 24, 1874), in PAPERS RELATING TO THE Foreign RELATIONS OF THE UNITED STATES 446 (1874). One note described a visit by a U.S. viceconsul and an Assistant U.S. Attorney to a German company in Germany seeking sworn testimony; when this was refused, the U.S. officials threatened that U.S. compulsory process would be issued and that the German company's U.S. business would suffer. The German note described this as a "trespass irreconcilable with the lawful rights and duties of the German authorities." Letter from Nicholas Fish to Hamilton Fish (July 27, 1874) and Letter from Mr. von Bülow to Nicholas Fish (July 25, 1874), in id. at 453-54.

91. Letter from Mr. von Bülow to Mr. Schlözer (Oct. 12, 1874), in id. at 463. 
rogatory," which it characterized as "the proper means to harmonize with our institutions and laws any necessity of American courts ... for the taking of testimony in Germany." The United States did not appear to object to this resolution. ${ }^{92}$

The Advisory Committee's revised proposal authorized, and indeed specifically invited, district judges and magistrates to ignore these settled principles of international law and to order that formal evidence-taking proceedings be conducted on foreign territory. Under the proposal, when use of the Hague Evidence Convention for discovery "at a place within a foreign [signatory] country" would be "inadequate or inequitable," a district court could "authorize other discovery methods not prohibited" by the Convention. 93 Of course, U.S. courts could have been expected to exercise restraint in ordering discovery on foreign territory in violation of foreign law; as discussed above, apparently without exception, they had refused to issue such orders even before the Advisory Committee's proposal. And, given the very real threat of foreign criminal or civil penalties, most U.S. lawyers would be very reluctant to participate in unauthorized coercive discovery on foreign territory. ${ }^{94}$

All of this suggests that the Advisory Committee's proposal probably would not have dramatically altered existing treatment of discovery that is formally conducted on foreign territory. But it is also possible that by prominently mentioning the possibility of ordering coercive discovery on foreign territory and by implying that no fundamental international law or other objections to such discovery existed, the amended blackletter language of Rule 26 would have had some effect on existing practice.

More importantly, the Committee offered no affirmative reasons to authorize evidence-taking on foreign territory in violation of international law. Almost all such discovery could be conducted in the United States-without violating international law-by requiring deponents, documents, or other materials to be transported to this country for depositions or production. In comparison, by formally conducting discovery on foreign territory, the United

92. Other nations encountered similar difficulties. For example, during the 19th century, an English barrister was imprisoned after he attempted to take testimony from witnesses in Germany pursuant to an English High Court commission, but without the supervision of Germany judicial authorities. A. JUNKER, DISCOVERY IN DEUTSCH-AMERIKANISCHEN RECHTSVERKEHR 219 (1987).

93. The Convention does not itself prohibit discovery of any sort-either on U.S. or foreign territory. Rather, as interpreted in Aérospatiale, the Convention affirmatively establishes various discovery mechanisms, without forbidding reliance on other means. The Convention's treatment of evidence-taking by consuls and commissioners does, however, suggest how the signatories viewed discovery formally occurring in another state's territory. The Convention contains detailed provisions that permit a commissioner or consul appointed by the requesting state to take evidence within a requested state. This departure from ordinary territorial limitations on enforcement jurisdiction was allowed, however, only with the consent of the requested state, on whose territory the proceeding was to occur.

94. There have been a number of incidents where U.S. attorneys, including some U.S. government attorneys, have faced foreign criminal action for violating local prohibitions on evidence gathering. See, e.g., Lionel Frei, Swiss Secrecy Laws and Obtaining Evidence from Switzerland, in 1 TRANSNATIONAL Litigation: PRACTICAL APPROACHES to Conflicts and ACCOMMODATIONS 1, 14-15 (Am. Bar Ass'n Nat'l Inst. ed., 1984). 
States would obtain little additional information while incurring all of the costs that accompany deliberate violations of international law and foreign territorial sovereignty.

The Advisory Committee's revised proposal also failed to address the most significant problems resulting from the Aérospatiale decision. In its revised form, the proposal did not directly address discovery "from" a foreign signatory state - such as requests for documents that are located abroad but that would be produced in the United States. By its own terms, the proposal dealt only with discovery "at a place within a foreign country," and not with discovery that formally occurred in the United States. ${ }^{95}$ The Advisory Committee Notes made this clear: "this rule does not apply to discovery of documents and things from parties who are subject to the court's personal jurisdiction and who may be required to produce such materials at the place of trial." 96

Nonetheless, the Committee's proposed revision could have had an indirect effect on discovery "from" foreign signatory states. The revision reflected a weighing of U.S. and foreign sovereign interests like that required by Aérospatiale's comity analysis. In this balancing process, U.S. interests in adequate and equitable discovery outweighed foreign interests-even where discovery was to occur on foreign territory in violation of foreign law. This proposed ordering of priorities would inevitably have reshaped Aérospatiale's interest-balancing framework, in cases involving discovery from foreign states, by decreasing the relative significance of foreign interests. ${ }^{97}$ The likely message of the revision for lower courts would have been: U.S. interests in adequate discovery outweigh even foreign interests in control over judicial proceedings on their own territory; U.S. interests, therefore, certainly outweigh more generalized foreign interests in privacy and judicial sovereignty.

To the extent that this proposition would have influenced U.S. courts, the scope of direct U.S. discovery would have been increased. While this might have benefitted some U.S. litigants in the short term, it would not have been a desirable outcome. Foreign signatories would have resented the expanded U.S. direct discovery as well as the reduced reliance on the Convention. In the longer term, more vigorous blocking legislation and other undesirable responses would likely have resulted. Disagreements over transnational discovery would have increased, foreign public policies would not have been respected, and private parties would have faced conflicting legal requirements from different nations.

95. 134 F.R.D. $525,641$.

96. Id. at 642 .

97. The U.S. Government's amicus curiae brief in Aérospatiale argued that foreign interests were implicated much more significantly when discovery occurred "on" foreign territory than when discovery "from" foreign territory was involved. Brief for the United States as Amicus Curiae at 25, Societé Nationale Industrielle Aérospatiale v. United States Dist. Ct. for the So. Dist. of Iowa, 482 U.S. 522 (1987) (No. 85-1695) ("Ordering that a foreign citizen be deposed on a foreign nation's soil obviously works a greater affront to that nation's territorial integrity than ... requiring a foreign corporation doing business here to make admissions that it has published advertisements in American magazines."). 
The Advisory Committee's revised proposal, however, was ultimately abandoned. First, in an unusual step, in the summer of 1991, the Supreme Court refused to adopt the proposed amendments to Rule 26, returning them to the Advisory Committee for further study. The Advisory Committee adhered to its proposal, albeit with the addition of generally helpful (but apparently insufficient) explanatory notes, ${ }^{98}$ and the Standing Committee (in another unusual step) rejected the proposed amendments. In late 1993, the revised Federal Rules of Civil Procedure went into effect without the proposed changes to Rule 26 . It now appears almost certain that the proposal has been abandoned.

\section{VI}

New Directions: Is There ANywhere to Go From AERospatiale?

It may be that disagreement about transnational discovery, particularly that involving the United States, is a problem that cannot presently be solved. At bottom, transnational discovery disputes arise from differing national conceptions of privacy, international law, the rights of litigants to disclosure of information from others, and the role of the judicial process in addressing social and economic ills. On many of these issues, there are important differences between U.S. and foreign views which may not be susceptible to any reasonable accommodation.

But the problem appears sufficiently serious to warrant efforts to try to solve it. Foreign nations have protested against extraterritorial U.S. discovery and believe that U.S. implementation of the Convention has been unsatisfactory. On the other hand, many in the United States feel that foreign nations unreasonably refuse to cooperate in U.S. discovery efforts based on narrow commercial interests. ${ }^{99}$ The disagreement has caused wasteful litigation, has produced foreign blocking legislation and other obstacles to transnational discovery, has subjected private parties to conflicting legal requirements, and threatens to frustrate international cooperation in other fields. Although there are more pressing problems on the agenda of international lawyers, extraterritorial discovery seems to be sufficiently important to justify exploration of new approaches.

\section{A. Scope of Discovery}

The basic framework for a compromise on extraterritorial discovery requires both the United States and its trading partners to moderate their positions on the acceptable scope of discovery. At present, the United States demands the

98. Proposed Revision of Federal Rule of Civil Procedure 26 and Proposed Advisory Committee Notes (June 1992), reprinted in BORN \& WESTIN, supra note 3, at 888-96.

99. Perhaps even more discouraging is the "number of commentators [that] have interpreted the French statute to express little more than simple hostility to American law." Brief for the United States as Amicus Curiae at 24, Aérospatiale (No. 85-1695) (citing Toms, supra note 32, at 586; Herzog, supra note 32). 
customarily broad discovery available under Rule 26 , modified on an ad hoc basis by lower court decisions that tailor or "pare down" extraterritorial discovery requests. Meanwhile, foreign states either flatly. refuse to permit pretrial discovery under the Convention or, more commonly, permit only narrow discovery of specific documents or classes of documents.

Although agreement may not ultimately be possible, it is not unreasonable to think that some compromise between these two extremes could be fashioned. Indeed, the past half-dozen years have seen groping efforts in this direction, with partial Article 23 reservations replacing absolute ones in Europe and with lower U.S. courts (and the Third Restatement) moderating the scope of U.S. extraterritorial discovery. ${ }^{100}$ The remaining task is to close the gap and formalize agreement on a standard of materiality falling between the present U.S. and foreign positions.

One possible formula would limit discovery to information that is material to the subject matter of the parties' dispute. The United States would make a concession to foreign interests by precluding "fishing" for information that might in turn lead to relevant evidence and by demanding, beyond mere relevance, a showing that the requested information has some meaningful effect on the disputed issues. Moreover, acceptance of this compromise would establish an across-the-board formula rather than the present ad hoc and unpredictable practice of "tailoring" discovery requests.

On the other hand, U.S. litigants would obtain significantly broader cooperation from foreign courts than is currently available. In particular, a "materiality" rule would not require a litigant to demonstrate that requested documents actually exist, and would not limit discovery to "specified" documents. These benefits would be most significant with respect to discovery from nonparty witnesses not subject to U.S. subpoena power. Because for these entities the Convention is currently the only means of discovery, an expansion in the scope of discovery under the Convention would be a substantial benefit. ${ }^{101}$

As to discovery from parties, the proposed compromise would provide U.S. litigants with a more mixed package. They would be denied the more expansive aspects of discovery available under Rule 26-although this is frequently unavailable even under existing practice. At the same time, they would be relieved of the unpredictability and expense associated with Aérospatiale's analysis as well as with the obstacles of foreign blocking statues. In addition, they would obtain greater certainty with respect to the enforceability of U.S. judgments abroad.

100. Hague Conference on Private International Law, Special Commission Report on the Operation of the Hague Service Convention and the Hague Evidence Convention, 28 INT'L LEGAL MAT. 1556, 1569 (1989).

101. It would also be possible to provide a different, narrower standard of discovery for witnesses than for parties. Such a policy, however, would frustrate U.S. goals, and it is not clear that it would significantly advance foreign interests. 


\section{B. Time Limits for Executing Requests}

Any effort to improve the Convention needs to ensure the speedy execution of letters of request. The Convention currently requires signatory states to execute incoming letters of request "expeditiously," but there is a widespread perception that this has often not occurred. A revised Convention could either include a fixed time limit for executing letters of requests (such as three months) or grant the requesting court the right to fix a time limit, subject to a minimum allowable time. This approach would, of course, impose an administrative burden on the courts of requested states. But, where the United States accommodates foreign states' demands that their courts be permitted to supervise discovery, it is not inappropriate to require in return that foreign courts accommodate the pace of U.S. pretrial proceedings.

A compromise could also address remedies in cases where time limits are not met. For instance, the new Convention could require the noncomplying requested state to provide a statement as to the circumstances of the delay and an undertaking of future compliance. In addition, in the event of noncompliance, the requesting state could be permitted to dispense with the Convention, either with or without a grace period. Moreover, provisions could be made for fee-shifting in cases where noncompliance resulted from a litigant's actions.

A compromise could also deal with the issue of expense. Compliance with the Convention's procedures generally imposes additional costs beyond those resulting from direct discovery, including the need for translations, foreign legal fees, and transportation. In some cases, these fees may materially affect the ability of a plaintiff to present his or her U.S. case; therefore, it might be appropriate, in such circumstances, to require or permit shifting of costs or fees. A party insisting upon use of the Convention's procedures, and deriving the benefits and protections of those procedures, might appropriately be required to pay for some or all of the additional financial burden imposed on the other party. ${ }^{102}$

\section{Procedures for Executing Discovery Requests}

A compromise on extraterritorial discovery also necessitates agreement on an acceptable procedure for taking evidence. Such a compromise requires meeting foreign demands for judicial supervision of the discovery process, without denying U.S. litigants their ability to initiate and pursue factual investigations. In principle, the objective of increased judicial involvement in discovery is not beyond reach. Similar objections exist in purely domestic U.S. contexts, and a reasonable argument can be made that all parties would benefit from greater judicial supervision. ${ }^{103}$

102. Any such fee-shifting ought to take into account the possibility that direct U.S. discovery might be more costly than use of the Convention, owing to its broader scope and party-controlled character.

103. Brazil, supra note 26, at 1295; see also COMMITTEE ON DISCOVERY, N.Y. STATE BAR ASS'N, REPORT ON DISCOVERY UNDER RULE 26(b)(1), 127 F.R.D. 625 (1989); Frank H. Easterbrook, 
The crucial issue in the context of the Convention is who would provide judicial supervision of U.S. discovery: U.S. courts, foreign courts, or some combination thereof. Two alternatives appear most promising. First, foreign courts could be responsible for executing U.S. discovery requests, subject to the requirements described above concerning scope and timing. By placing decisions on the reach of U.S. discovery in foreign hands, the United States would make a significant concession, substantially allaying foreign concerns about the proposed compromise. United States courts could retain the power to order direct U.S. discovery in a limited set of circumstances following foreign execution of a letter of request. For example, direct U.S. discovery could proceed after a U.S. court concluded that the Convention's provisions, including those relating to scope of discovery, had been materially breached. A variety of modifications to this formula could be explored, including heightened standards of proof, requirements for detailed factual and legal findings, and alternative formulations of the "material breach" requirement.

A second approach would require any U.S. letter of request to gain approval in advance from a U.S. judicial authority after notice and an opportunity for a hearing. Once approved by a U.S. judge or magistrate, a letter of request would be entitled to a presumption of validity in foreign courts, which would be charged with executing the request. In approving letters of request, U.S. courts would, of course, apply the Convention's (new) limits on the scope of discovery. A foreign court could overturn the U.S. determination only upon a specific finding, perhaps by some heightened standard of proof, that the Convention did not authorize the request. If a foreign court reached such a conclusion, then direct U.S. discovery would be available, subject perhaps to a requirement that the U.S. court reconsider the issue and specifically conclude that the foreign court had materially breached the Convention.

Both approaches seek to provide judicial supervision of U.S. discovery, without compromising the party-directed character of U.S. factual investigation. Nonetheless, objections to these proposals are likely to surface. One line of objection will no doubt be that both approaches invite the courts of one nation to sit in judgment on a foreign state's adherence to the Convention, thereby provoking unseemly transatlantic fingerpointing. This objection, however, does not warrant rejecting either approach. Judicial scrutiny of foreign states' compliance with treaty obligations already exists in some fields ${ }^{104}$ and ought not be unacceptable in principle. Moreover, both alternatives are structured to facilitate compromise and deference, and to limit judicial second-guessing to extraordinary cases. Any resolution of transnational discovery disputes will require cooperation-and inevitably disagreement-between national authorities. The two suggested approaches do involve some measure of second-

\footnotetext{
Comment, Discovery as Abuse, 69 B.U. L. REV. 635 (1989).

104. E.g., Kalamazoo Spice Extraction Co. v. Provisional Military Gov't of Socialist Eth., 729 F.2d 422 (6th Cir. 1984) (considering challenge to Ethiopia's compliance with Treaty of Amity).
} 
guessing, but the number of disputes likely to result from either compares favorably with the existing situation.

\section{Privileges}

Any compromise affecting transnational discovery also needs to address the subject of privileges. In addition to permitting less expansive factual investigation than is available in the United States, foreign states generally recognize different, and sometimes broader, privileges. At present, U.S. courts generally respect foreign privileges where they are properly applicable under choice of law rules; ${ }^{105}$ at least in principle, therefore, the United States ought to be able to forego discovery in situations where a foreign privilege so requires. ${ }^{106}$

Two important caveats are necessary. First, it would be practicable to require nations to provide detailed listings and descriptions of local privileges in advance. Where a nation wishes a release from its obligation to execute a letter of request, it can appropriately be expected to have provided advance notice of its intentions.

Second, some civil states might wish to assert broad "business" or "trade" secrets privileges. ${ }^{107}$ From a U.S. perspective, recognizing such privileges would largely eviscerate the Convention. Acknowledging such privileges would also probably be unnecessary to protect foreign interests. Comparative law studies suggest that foreign "business secrets" privileges serve principally to limit the use of proprietary commercial information by competitors. ${ }^{108}$ Because this objective could be largely achieved through the use of protective orders, redaction, in camera hearings, and similar devices, outright withholding of material evidence would not be necessary.

\section{E. Equality of Treatment}

Finally, any proposed revision of the Convention must satisfy U.S. and foreign requirements of procedural fairness and equality of treatment of parties. Most importantly, from a U.S. perspective, parties from Convention signatories

105. See BORN \& WESTIN, supra note 3, at 404-05.

106. The Hague Evidence Convention presently deals with the subject of privilege in Article 11, providing that evidence may be withheld where a "privilege or duty to refuse to give evidence" exists "under the law of the State of execution" or, in some cases, the law of the requesting State. Convention on the Taking of Evidence Abroad in Civil or Commercial Matters, supra note 5, art. 11, 23 U.S.T. at 2561, 847 U.N.T.S. at 243.

107. Gerber, supra note 31.

108. Id. 
ought not enjoy discovery or other litigation advantages over U.S. litigants. ${ }^{109}$ To achieve this end, the U.S. side would likely insist upon two safeguards.

First, litigants from signatory states would not be permitted to obtain discovery on broader or more expeditious terms than they were required to give. As Justice Blackmun's concurring opinion in Aérospatiale observed, district judges presently have the power under the Federal Rules of Civil Procedure to so limit discovery:

Courts can protect against the [concern] that a foreign party to a lawsuit would have a discovery advantage over a domestic litigant ... by exercising their discretionary powers to control discovery in order to ensure fairness to both parties .... If, for instance, resort to the Convention procedures would put one party at a disadvantage, any possible unfairness could be prevented by postponing that party's obligation to respond to discovery requests until completion of the foreign discovery. ${ }^{110}$

Any proposal to revise the Convention should clearly recognize the necessity of treating all parties equally with respect to discovery opportunities, including by means of limiting otherwise available U.S. discovery.

Second, the proposed compromise could also implicitly or explicitly affirm the right of national courts-and particularly U.S. courts-to apply presumptions, burdens of proof, and other evidentiary devices to ensure a level litigation field. Equalizing discovery opportunities does not assist a party who bears the burden of proof on an issue as to which effective discovery is not available. Although the compromise proposed here ought to permit effective discovery in most cases, a residual power to adjust evidentiary requirements might be appropriate.

\section{VII \\ CONCLUSION}

The post-Aérospatiale resolution of transnational discovery disputes satisfies virtually no one. Foreign states resent the refusal of U.S. courts to make use of the Convention and their disregard for local conceptions of judicial sovereignty. The United States is frustrated by foreign states' Article 23 reservations and blocking statutes, as well as by the unwieldy character of the Aérospatiale analysis.

Real substantive differences concerning the appropriate scope and means of discovery may preclude any early resolution of transatlantic discovery disputes. Given the apparent seriousness of the problem, however, it is at least worth

109. This was a concern underlying rejection of the first-use rule in Aérospatiale:

[W]ithin any lawsuit between a national of the United States and a national of another contracting party, the foreign party could obtain discovery under the Federal Rules of Civil Procedure, while the domestic party would be required to resort first to the procedures of the Hague Convention. This imbalance would run counter to the fundamental maxim of discovery that "mutual knowledge of all the relevant facts gathered by both parties is essential to proper litigation."

Société Nationale Industrielle Aérospatiale v. United States Dist. Ct. for the So. Dist. of Iowa, 482 U.S. 522, 540 n.25 (1987) (quoting Hickman v. Taylor, 329 U.S. 495, 507 (1947)).

110. Id. at 565-66. 
exploring the possibilities of a compromise. One framework for a settlement would involve the following elements:

1. A U.S. commitment to use the Convention, except where a foreign signatory has materially breached its terms;

2. Deletion of Article 23 (or revocation of Article 23 reservations) and agreement on the scope of discovery that must be permitted, such as discovery of all information material to the parties' dispute;

3. Agreement on an effective means of judicial supervision of evidencetaking under the Convention, such as initial judicial scrutiny and approval of letters of request in the requesting state coupled with some form of deference to such approval in the requested state;

4. Agreement on fixed time limits for the execution of most letters of request;

5. Provisions for fee-shifting in cases requiring translations and other defined expenses; and

6. Agreement on mandatory recognition of most foreign privileges, provided they are identified and described in the foreign state's accession.

These six points merely illustrate one possible compromise. A wide range of modifications or refinements would be possible, depending ultimately on the objectives of the affected states.

Though it may seem unduly optimistic, the differences that presently separate the United States from its principal trading partners do not appear so great as to foreclose a compromise along the above lines. In the end, one or more of these differences may prove unbridgeable, or the existing status quo may not be as objectionable as public rhetoric suggests. Nevertheless, the persistence and vigor of complaints about the status quo and the possibilities for a new, more durable compromise are sufficient to justify further exploration. 